\title{
Redefining "Public" Water Supplies, 1870-1890: A Study of Three Iowa Cities
}

\section{MAUReEN OGLe}

WITHOUT WATERWORKS, warned a Boone, Iowa, newspaper reporter in 1882, the city would "surrender," and "sink into the condition of a small way station in the map of Iowa." That journalist was not alone in his views. In Iowa City and Marshalltown, too, residents actively sought the construction of waterworks as a way to lure manufacturers and "capitalists," as well as to increase city populations. These Iowans perceived a waterworks-that is, a central pumping station that provided a steady pressurized water supply through a network of mains-as a necessary attribute of a "live" city; without one a city would be unable to attract new residents or manufacturers. Their belief spurred them to act: between 1876 and 1885 residents in these three cities took steps to ensure the construction of waterworks, a process that involved more than issuing bonds, hiring engineers, and passing ordinances. It also required that city residents adopt new ideas about the form and uses of a city water supply. It required them, in other words, to redefine the meaning of a "public" water supply."

1. Boone Standard, 3 June 1882. These three cities were chosen in part for their accessibility and the availability of official documents. But they are also representative of small American cities in the late nineteenth century. All three were-and are-small, yet each had a different economic base: Iowa City had a state university; Marshalltown developed a considerable manufacturing base-after building a waterworks; Boone served as a district headquarters for the Chicago and North Western Railroad. There was very little about the three that distinguished them from hundreds of other small cities that dotted the American landscape in the late nineteenth century.

THE ANNALS OF IOWA 50 (Summer 1990). CThe State Historical Society of Iowa, 1990. 
Historical research into the development of American municipal water supplies has proceeded slowly since the publication of Nelson Blake's landmark Water for the Cities in 1956. Because Blake focused on the experiences of just a few large American cities between about 1790 and 1860, his book, important though it is, can scarcely be considered the last word on the subject. Unfortunately, most subsequent studies have also focused on large cities that established municipal water supplies prior to about 1870 . Moreover, these studies have usually placed the history of municipal water supplies within the context of the combined forces of urbanization, science, and technology, which drove Americans to build waterworks. That is, faced with a crisis of urbanization and the attendant overcrowding, rampant disease, and conflagrations, city leaders, aided by advances in technology and new knowledge about diseases, responded by building waterworks. ${ }^{2}$

2. Nelson Blake, Water for the Cities: A History of the Urban Water Supply Problem (Syracuse, NY, 1956). No other historian has tackled the subject on such a broad scale as Blake, although Louis Hunter's discussion of the technology of urban water supply comes close. See Louis Hunter, Steam Power: A History of Industrial Power in the United States, 1780-1930 (Charlottesville, VA, 1985), 509-93. Urban history surveys that discuss water supplies tend to generalize about all American cities based on the cases of a few, or to focus on the political aspects of water supply development. See, for example, Sam Bass Warner, Jr., The Urban Wilderness: $A$ History of the American City (New York, 1972), 25, 202-3; Ernest S. Griffith and Charles R. Adrian, A History of American City Government: The Formation of Traditions, 1775-1870 (1976; reprint ed., Washington, DC, 1983), 70-74; Charles N. Glaab and A. Theodore Brown, $A$ History of Urban America (New York, 1967), 97, 175; Daniel J. Boorstin, The Americans: The Democratic Experience (New York, 1973), 347-50. For studies of individual cities that emphasize the post-Civil War era, see Stuart Galishoff, Newark: The Nation's Unhealthiest City, 1832-1895 (New Brunswick, NJ, 1988), 163-66; Bruce Jordan, "Origins of the Milwaukee Water Works," Milwaukee History 9 (1986), 2-16; Willard I. Toussaint, "'The Fire Fiend Doffs His Hat': Burlington's First Water Works," Annals of Iowa 38 (1967), 510-26; John Ellis and Stuart Galishoff, "Atlanta's Water Supply, 1865-1918," Maryland Historian 8 (1977), 5-22; Stuart Galishoff, "Triumph and Failure: The American Response to the Urban Water Supply Problem, 1860-1923," in Pollution and Reform in American Cities, 1870-1930, ed. Martin V. Melosi (Austin, TX, 1980), 35-57; Terry S. Reynolds, "Cisterns and Fires: Shreveport, Louisiana, as a Case Study of the Emergence of Public Water Supply Systems in the South," Louisiana History 22 (1981), 337-67. Of these individual studies, all but Reynolds's emphasize the political machinations involved in establishing water supplies, rather than the ideas that shaped the decisions. 
There are some problems with this assessment. Most American cities that built waterworks in the second half of the nineteenth century were not like New York, Chicago, Boston, or Philadelphia, nor did they face the problems that troubled those large cities. For cities with populations between five and ten thousand, overcrowding, rapid growth, and massive industrialization were not pressing problems. New York City may in fact have built the Croton water system in response to the pressure of a population close to a half million, but that does not explain why hundreds of small American cities, many with populations of just a few thousand, built waterworks when they did.

The history of municipal water supplies in Boone, Marshalltown, and Iowa City, Iowa, suggests a different explanation. All three built waterworks between 1875 and 1885 , before their population reached ten thousand; by 1895 only Marshalltown had barely squeaked past that mark. ${ }^{3}$ In these cities, then, the decision to build waterworks involved more than a reflex response to urban growing pains. Rather, the introduction of this important municipal utility actually facilitated urban growth, without the stimulus of some external crisis.

DURING THE 1860s city councils and newspapers in Iowa City and Marshalltown often discussed the problem of water, or, more specifically, the problem of securing sufficient water to fight fires. ${ }^{4}$ Until the early 1870 s townspeople perceived public water supplies as part of an "efficient" fire fighting

3. More information on the three cities is in Judge William Battin and F. A. Moscrip, Past and Present of Marshall County, Iowa (Indianapolis, 1912); History of Johnson County, Iowa (Iowa City, 1883); N. E. Goldthwait, History of Boone County, Iowa (Chicago, 1914). By 1866 all three cities were not only incorporated, but had been classified as cities of the second class, meaning their populations had reached or exceeded two thousand. Populations for the three cities in 1870 were: Iowa City, 5,914; Marshalltown, 3,218; Boone, 2,415. By 1895 the figures were: Iowa City, 7,526; Marshalltown, 10,049; Boone, 8,845. Population data taken from The Statistics of the Population of the United States, Ninth Census, vol. 1 (Washington, DC, 1872), and Census of lowa for the Year 1895 (Des Moines, 1896).

4. Both newspapers and city council minutes are strangely silent about the subject of water in Boone until the early 1870 s. 
operation, rather than as a multipurpose urban amenity. For example, in the early 1860 s the Iowa City city council created two standing council committees as part of a short-lived effort to help volunteer fire fighters. One group served as overseers of the fire companies and equipment; the other organized construction of public cisterns for use by fire fighters. Both committees disbanded after just two years, but in 1869 citizens revived the subject of fire protection, leading city officials to authorize construction of a new public cistern in the business district. Similarly, one of the first mentions of a water supply in Marshalltown centered on fire protection. A letter published in a local newspaper in 1866 noted that, despite all the boasting about the town's size and industrial base, Marshalltown had no protection against fire, not even a "town well or cistern." City council members responded to the criticism by building two five-hundred-barrel cisterns. A set of "conductors" carried water from a source-probably a well or the creek that ran through town-to the brick cisterns. In 1868 , after the town's population reached two thousand and it was reclassified as a second-class city, one local newspaper called for fire protection in the form of, among other things, an increased water supply. So integral was the connection between water supply and fire fighting needs that a Marshalltown newspaper reported that many residents opposed an 1868-1869 city council plan to buy fire fighting equipment because there was not enough water available to make the purchase worthwhile. ${ }^{5}$

Clearly, councils in these two cities accepted the responsibility for using tax money to provide a public water supply. Yet there is no evidence from the 1860 s that city officials built cisterns or dug wells to provide water supplies for anything but

5. Minutes of the Iowa City City Council, 9 April 1861, 18 April 1862, City Clerk's Office, Iowa City City Hall, and Johnson County Historical Society (hereafter cited as Minutes-Iowa City); Marshall County Times, 14 November 1866, 7 March, 5 December 1868; Minutes of the Marshalltown City Council, 13, 27 March, 29 May 1867, City Clerk's Office, Marshalltown City Hall (hereafter cited as Minutes-Marshalltown). In Boone fire fighters had access to several wells and cisterns by late 1871. Montana Standard (Boone), 30 July 1870; Boone County Advocate, 16 February 1871; Boone County Democrat, 1 November 1871 . 
fire fighting, nor was a public water supply ever defined as anything more than one part of a fire protection system. ${ }^{6}$ Indeed, prior to the construction of waterworks, all issues relating to water supplies were handled by city council Committees on Fire or city fire chiefs.?

Because residents defined a municipal water supply in terms of fire fighting, they selected both the technology and the location of the water supply to suit that purpose. Since bucket brigades delivered water directly from the source to the fire or to the hand pump fire engines, all that was required were convenient storage containers; it was not necessary to "pipe" water to every block and building in the community. By the early 1870 s all three cities had collections of water storage units-wells, cisterns, or reservoirs-located in each city's "business blocks," where residents saw the greatest need for protection.

THE PUBLIC'S UNDERSTANDING of both the purpose and the form of a municipal water supply was transformed during the 1870s. By the end of the decade all three cities either had erected or were considering the construction of waterworks designed to supply water not only for fire fighting but for domestic and manufacturing purposes as well. By 1877 Marshalltown residents enjoyed water from seven miles of mains, and an intense debate about the prospect of building a pressurized city waterworks system engaged the attention of Boone and Iowa City residents. The shift from a single-purpose to a multipurpose water supply began in the first half of the 1870 s.

6. There is virtually no evidence in the newspapers and city council minutes for the 1860 s to support a claim that city councils provided water for domestic use, but quite a lot that demonstrates that they provided a public water supply for the sole purpose of fighting fire.

7. Minutes-Marshalltown, 9 May, 12 September 1870; Minutes-Iowa City, 13 December 1872; Montana Standard (Boone), 30 July 1870; Minutes of the Boone City Council, 18 June 1873, 5 May 1875, City Clerk's Office, Boone (hereafter cited as Minutes-Boone). Once waterworks had been constructed, councils in all three cities created standing Committees on Water, and turned the management of water supplies over to designated managers. 
Between 1872 and 1875 all three cities continued to enlarge existing water supplies by building more cisterns and wells. In Iowa City and Marshalltown, however, local newspaper editors also began promoting the idea of expanding both the scope and the technology of local water supplies by building waterworks. These efforts coincided with a national "mania," as one Marshalltown paper labeled it, for the so-called Holly system of waterworks. Using turbine wheels to operate a series of rotary force pumps, the Holly method provided pressurized water; both the water supply and pressure could be regulated "in exact proportion to the demand." According to the popular national magazine Scientific American, the Holly pumps acted in conjunction with a "hydrostatic pressure regulator" that doubled or tripled ordinary pressure within twenty seconds when needed. In addition, the manufacturers guaranteed that, thanks to this immense pressure, hoses supplied by a Holly system threw water one-quarter to one-third farther than a conventional steam fire engine. "Every building can have within it an effective extinguisher, and every private hydrant . . . becomes a fire engine," the Scientific American gushed. ${ }^{8}$

The possibilities of the system were apparent to local newspaper editors, too. "Every town of any considerable size, is clamourous [sic] for it," announced a Marshalltown paper; building a works and selling water to families on a yearly basis was as sound an investment as Marshalltown taxpayers could make. ${ }^{9}$ In Iowa City, too, a newspaper editor waxed rhapsodic on the charms of the Holly, seeing in it a potential that went far beyond the needs of fire fighters. Using Holly pumps to carry water from the river, argued the writer, would eliminate the need for cisterns and allow "manufacturing interests" to move in closer to the city "where they should be," rather than clustering around dams built a few miles upriver from Iowa City, near

8. Marshall County Times, 30 November 1871; Scientific American 25 (1871), 345. More information on the Holly system is in Letty Donaldson Anderson, "The Diffusion of Technology in the Nineteenth Century: Municipal Water Supply Investments" (Ph.D. diss., Northwestern University, 1980), 21-22; and Hunter, Steam Power, 561-62.

9. Marshall County Times, 30 November 1871, 25 January 1872. 
the tiny town of Coralville. ${ }^{10}$ The writer envisioned a day when factories would line the river bank, forming "the great beating heart of the town." Moreover, he noted, the cholera plague "avoided" the nation's large cities, such as New York and St. Louis, because those places had invested in waterworks and sewers. "Smaller towns" had not, because they "think their smallness is an element of safety." They sleep "in the midst of bad odors and filth and they never wake up for the cholera comes and they collapse."11

In Iowa City and Marshalltown, then, the element of city size and prosperity entered the argument for a citywide water supply early in the 1870 s; the newspaper editorialists had placed their cities within a particular urban framework. Having a Holly system, the Marshalltown editor implied, would ally the city with others of "considerable size." The Iowa City editor explicitly linked his community with larger cities, and he delineated characteristics that distinguished "smaller towns," namely, lack of manufacturing and a propensity toward disease, which led to municipal "collapse."12

The first half of the 1870 s proved an inauspicious time for major municipal spending in these three cities, however. Despite an 1872 Iowa law that encouraged the construction of municipal utilities by allowing cities and towns to levy a special tax to pay for the operation of waterworks or to pay for water

10. Iowa City Daily Press, 17 May 1872, 2 September 1873. If contemporary descriptions can be believed, the bustle of nearby Coralville, incorporated in 1866, must have made many Iowa City boosters uncomfortable. River falls located near Coralville made the location an excellent one for manufactories of all kinds. From one grist mill built in the 1840s, Coralville's commercial activity had, by the 1870 s, expanded to include paper, planing and saw mills, as well as a mill that produced, according to one source, ten thousand yards of fabric per month. See History of Johnson County, 729-31.

11. Iowa City Daily Press, 17 May 1872, 2 September 1873. The editor of the Iowa City Daily Press at that time was John P. Irish, the brother of George Irish, a prominent engineer and surveyor. It is possible that the latter's professional activities and work, which took him to all parts of the country and in fact included designing a sewer plan for Iowa City, influenced his brother to stay abreast of the latest in engineering and municipal technologies.

12. A broader discussion of the meaning and importance of city size and its impact on city activities is in Maureen Ogle, "Urban Growth in Iowa: Defining and Creating the Small City, 1870-1890". (Master's research essay, Iowa State University, 1988). 
rents when a private corporation built them, enthusiasm for the Holly system could not overcome a general reluctance to alter the nature of existing water supplies. The Chicago fire of 1871 may have prompted the "mania" for Holly waterworks systems. Local newspapers devoted considerable space to the fire, which certainly lodged fear, if not inspiration, in the hearts of some citizens, and may have prompted many American cities to contemplate increasing water supplies in preparation for a similar event. Moreover, Holly and other purveyors of waterworks technologies seized the moment and actively marketed their products throughout America in the early 1870s. ${ }^{13}$

Shortly after the Chicago fire, the Marshalltown city council contemplated submitting to voters a twenty-five-thousanddollar bond issue to fund construction of a waterworks. City officials considered the works only as a way to increase the supply of water for fire fighting, rather than as a general purpose water service. After deliberation they vetoed the idea. ${ }^{14}$ When a disastrous fire destroyed a large part of the business district in May 1872, however, pressure mounted to build a Holly works-or something similar. A petition from residents urged the council to act, claiming the "time [had] come" when the city

13. An Act authorizing Cities, incorporated Towns and Villages to construct, or cause to be constructed, Water-works, 1872 lowa Acts, 80 . Anderson, "The Diffusion of Technology in the Nineteenth Century," credits the popularity of the Holly system and its competitor, the Worthington pump, to aggressive "market organization," as does George W. Fuller, "Water-works," Proceedings of the American Society of Civil Engineers 53, part 2 (1927), 1587. Published as part of the proceedings from an ASCE symposium entitled "Historic Review of the Development of Sanitary Engineering in the United States during the Past One Hundred and Fifty Years," Fuller's essay notes that as early as 1887 J. James Croes's Statistical Table of American Water Works credited manufacturers with promoting the idea of pressurized waterworks, especially during the 1870 s. What neither Croes, Fuller, nor Anderson point out, however, is that people rarely manufacture, promote, or acquire goods that are not perceived as being useful or appropriate; in other words, a multipurpose citywide waterworks may have been a technology whose time had come. Since cities as small as Boone and Iowa City were seeking them out, where similarly sized cities had not done so in earlier decades, one can conclude that ideas about appropriate technologies had changed during the course of the century. However, Louis Hunter, Steam Power, 532-33, 548, also notes that the desire to pump directly into mains, rather than to reservoirs, helped spur the development of these pumping engines.

14. Minutes-Marshalltown, 7, 16 October, 13 November 1871. 
fathers were "fully justified" in taking "speedy and efficient measures to protect the City from a repetition of the late destructive conflagration." As a result, several council members and the fire chief traveled to Peoria, Illinois, to study that city's waterworks and fire department. ${ }^{15}$

The project ended with the trip, however, and the council turned instead to other means of enlarging the city water supply. Between 1872 and 1875 Marshalltown administrators authorized four more cisterns. In cooperation with the Chicago and North Western Railroad, which ran through the city, the council also installed a fire plug in the business district and laid a main from it to the railroad's water tank. This tiny water system served only the business blocks and was built for the sole purpose of fighting fires. In addition, the council ordered its Committee on Fire to dig a new well, not in the town center as had been customary, but at a nearby spring, apparently hoping to find a more permanent supply of water than that available from existing cisterns. ${ }^{16}$

In lowa City, too, the idea of building a waterworks lapsed. One editor collected information on waterworks in Ogden, New York; Peoria, Illinois; and Davenport, Iowa. He also reprinted articles on the subject from Marshalltown papers. Despite these efforts, the council ignored the information and instead built more cisterns. ${ }^{17}$

In Boone, which had been less active in the 1860 s, the Chicago and North Western offered the city a water supply similar to the one it had helped establish in Marshalltown. In the summer of 1873, after negotiating with the railroad, the city council appropriated the funds necessary to run four hundred feet of three-inch cast iron pipe to two hydrants located on Main Street. After workers completed the project, a city newspaper

15. Minutes-Marshalltown, 7, 13, 27 May, 10 June, 19 August, 9 September, 15 Octóber 1872. Peoria actually had a Worthington system of waterworks, which, like the Holly, was based on pumps and pressure. A brief description of the Peoria works is in Moses N. Baker, Manual of American Water-works, 4th issue (New York, 1897), 387-88. For a larger discussion of the Worthington pumping engine, see Hunter, Steam Power, 548-53.

16. Minutes-Marshalltown, 21 October, 11 November 1872, 20 July 1874.

17. Iowa City Daily Press, 25, 30 May, 3 June 1872; Minutes-Iowa City, 13 December 1872, 15 December 1873. 
pronounced it "one of the best things" done in Boone for many years. The water pressure, noted the paper, threw a stream sufficient to reach the top of any building on the main business block. As in Marshalltown, the project provided more water for fire fighters, rather than for general use. ${ }^{18}$

During the first half of the 1870 s, then, each of these cities enlarged supplies of water for fighting fires, but proposals to alter the nature of public water supplies elicited no action. Despite the enthusiasm for waterworks nationally, each of these cities waited; waterworks construction occurred not at the height of such enthusiasm, but later. When these cities finally did construct water utilities, they did so not in response to a crisis spawned by urbanization or industrialization, but out of an impulse to keep pace with other municipalities, and to promote themselves as "live" and progressive communities. Moreover, city leaders based their construction plans on a new conception of the uses and form of a water supply. They abandoned the belief that a public water supply should be for fire only, and consequently selected a different kind of technology, a largescale pressurized waterworks, to be built either at taxpayers' expense or by private companies. The new waterworks provided general-purpose water citywide, rather than in the "business blocks" for fire protection only. This shift followed a different path in each of the three cities, but fundamental similarities underlie the individual differences.

MARSHALLTOWN preceded the other two cities in building waterworks. At first glance its history appears to contradict the claim that waterworks construction was not prompted by a state of crisis. In April 1876 a major fire destroyed almost thirty thousand dollars worth of property, prompting one local newspaper to enter another plea for a waterworks. It would lower fire hazards and insurance rates, the writer declared, as well as promote "cleanliness, health, and comfort, and manufacturing interests. ${ }^{19}$ This time the council needed little prompting.

18. Boone County Democrat, 20 November, 4 December 1872, 6 August, 17 September 1873; Minutes-Boone, 11 December 1872, 15 January, 18, 25 June, 30 July 1873.

19. Marshall Daily Times, 1 May 1876. For a description of the fire, see ibid., 6 
Within days it ordered its Fire Committee to obtain "all the information [it could] get" with an eye to building a waterworks for "fire protection and domestic uses." 20

In a joint effort, the entire council, along with the mayor and a local reporter, departed on a fact-finding mission, their journey eased by free transportation provided by the Chicago and North Western Railroad. The group traveled to Cedar Rapids and Clinton, Iowa, and to Racine, Wisconsin, and Chicago to study both municipal and manufacturing waterworks. According to the reporter, the trip convinced city officials that a waterworks, "without which no town or city [could] be healthy," was necessary in order for Marshalltown to take its place among the "leading, live, wide-awake" cities of the state. "No city of 5,000 inhabitants [could] afford to use well water for domestic purposes," he acknowledged, but there was a "sufficient argument for water works in the matter of health alone." The issue of water supply no longer centered exclusively on fire protection. Within two months of the fire, the city had issued fifty thousand dollars in bonds to pay for the works, and hired an engineer to superintend its construction. "Halelujah [sic] 'Tis Done," crowed a local newspaper after the council voted to move ahead with the project. ${ }^{21}$

As construction got under way, city lawmakers passed several ordinances designed to regulate the use and management of the waterworks. One ordinance created a waterworks department and a board of commissioners, chosen from among the councilmen themselves, to oversee the construction and management of the plant. The ordinance empowered the commissioners to "hire, fire, act [and] make rules and regulations for governing the water works." A second ordinance outlined the rules and regulations by which the works was to be governed. Its text indicates clearly that the water was for multiple purposes: the ordinance included rules for using water on lawns

April 1876, and Battin and Moscrip, Past and Present of Marshall County lowa, 426-27.

20. Minutes-Marshalltown, 17 April 1876. See also Marshall Daily Times, 17, 19 April 1876.

21. Marshall Daily Times, 5, 10, 12, 15 May 1876. See also MinutesMarshalltown, 12, 13, 22 May, 10, 12 June 1876; Marshall Daily Times, 2, 3, 4, 8, 13 May 1876. 
and for fountains, and established rates for a wide variety of customers, from private homes with baths and water closets to manufacturers, barbers, and liveries. ${ }^{22}$

Completed in January 1877 and drawing from the Iowa River, the works' two "Knowles direct acting double pumps" provided the city with two million gallons of water each day, carried through seven miles of mains, and served 216 users and 55 hydrants stationed throughout the city. The thoroughness of the works, noted the water department in its first annual report, allowed every customer to have a "small fire engine at his command." The list of water customers included private homes and a wide variety of commercial enterprises. This marked a shift in the way people perceived a public water supply, for city residents clearly intended to use the water as more than a "small fire engine." ${ }^{23}$

It is equally clear that although the 1876 fire prompted this municipal commitment, the fire alone was not sufficient to spur the people of Marshalltown to action. Nor did a sudden population surge and the resulting chaos often associated with rapid urbanization propel these Iowans to act as they did when they did. Rather, they acted primarily out of a desire to keep pace with other cities of similar size. By the time Marshalltown's works opened, six other Iowa municipalities-Anamosa, Cedar Rapids, Clinton, Davenport, Des Moines, and Dubuquealready enjoyed water service. ${ }^{24}$ It is true that promoters cited

22. Minutes-Marshalltown, 15, 22, 28 June, 4 September 1876; An ordinance in relation to water commissioners, and water works for the city of Marshalltown, Marshalltown Ordinance Record No. 1, 308-13; An ordinance concerning the water works department of the city of Marshalltown, Iowa, and establishing water rates, rules, regulations and penalties for the government of water taking, licensed plumbers and others, ibid., 333-45; An ordinance prohibiting the pollution of the Iowa river above the point where the city of Marshalltown draws water for its system of water works, and for the protection of said works, together with the machinery, pipes, hydrants, and other apparatus connected therewith from injury and damage, ibid., 347-50. Ordinance Record Books are held at the Marshalltown City Clerk's office.

23. First Annual Report of the Water Works Department (Marshalltown, 1878). For various reports on the construction and testing of the works, see Marshall Daily Times, 3, 28 August, 13 October 1876.

24. See Baker, The Manual of American Water-works, 412-38. Another source of information on lowa waterworks is John H. Dunlap, Water Works Statistics 
health and cleanliness as incentives for construction. In Marshalltown's case, however, the point of using health as a reason for building was not to combat an upsurge in disease, but rather to prevent disease from becoming a major problem and to ensure the city's reputation as a healthy place to live and work. ${ }^{25}$

That the Marshalltown and other Iowa municipal waterworks constituted both a major achievement in fire protection and a tremendous attraction to prospective manufacturers was a point not lost on the citizens of Boone and Iowa City. The connection between a waterworks and prosperity had been firmly implanted in many minds in the two communities: if they were not merely to survive, but also to prosper and grow, then a waterworks they must have. As one Boone resident said, in a letter to a newspaper, "any smart looking town" owed its appearance to "improvement, water works, gas works," and Boone must work toward those things if it was to stand "shoulder to shoulder with other cities in Iowa." 26 .Both cities sought waterworks as a way to keep pace with Marshalltown and other Iowa cities, and to enhance their reputations. By the end of the decade residents in both places were articulating a new attitude toward the notion of public water and its uses. During 1879 and 1880 these sentiments blossomed into an active effort by "leading citizens" and city councils to provide residents with a general purpose water supply, one marked by careful study of other municipalities, and by input from local taxpayers and businessmen. ${ }^{27}$

of Thirty-eight Cities of Iowa, University Extension Bulletin No. 8, Bureau of Municipal Information (Iowa City, 1914).

25. Studies that explain American waterworks construction throughout the century in terms of disease, overcrowding, and the like include Glaab and Brown, A History of Urban America, 164-65; Joel A. Tarr, "Building the Urban Infrastructure in the Nineteenth Century: An Introduction," in Infrastructure and Urban Growth in the Nineteenth Century (Chicago, 1985), 65-66; and Galishoff, "Triumph and Failure." A more careful assessment of the development of a multipurpose water supply, but one that ultimately finds causation in disease, is John Duffy, A History of Public Health in New York City, 16251866 (New York, 1968), 392-96.

26. Boone County Republican, 17 March 1880.

27. Based on her research of small New England cities, Anderson, "The Diffusion of Nineteenth Century Technology," "tentatively" concluded that "the 
In Iowa City, for example, the subject of water took on a new cast when the diverse issues of sewage, inadequate drainage, and community prosperity collided with a momentum that propelled the city council to readjust its ideas about city water supplies. In the spring of 1874 property owners adjacent to the city's largest hotel began complaining to city officials that the business had become a nuisance. Its waste products overwhelmed the drainage ditch that ran down the middle of the closest street, spilled over onto adjoining property, and left a stagnant mess in the creek into which the ditch drained. The dilemma perplexed local aldermen: how could they correct a situation that was clearly a nuisance and thus a public offense, and yet maintain support for a badly needed commercial enterprise? ${ }^{28}$

A special committee studied two possible solutions: building a five-block-long concrete sewer to enclose and direct the sewage away from private property, or installing a wind-driven pump in a well to flush the creek into which the sewage drained. The same newspaper that earlier had touted the Holly system seized upon the sewer plan as another reason to install a waterworks. The hotel sewer could serve as the "nucleus" of a general system of underground drainage, it argued, and a waterworks was a "necessary collateral" for the system. The writer urged the council to recognize the "city's obligation to supply every facility becoming our high character, . . . and required to transact business and secure the health" of the citizens, and noted that Cedar Rapids, Clinton, Marengo, and "other minor towns" in Iowa were seriously considering constructing waterworks. "Where are the water works?" the newspaper queried during the summer of 1874 , arguing that water would eliminate vile wells, dusty streets, hot pavements, and wilted trees. The city council, although conceding that water would help push the sewage into and along the course of the

time at which an individual town adopted a water works system seems to have been determined in part by the influence of larger cities which may have served as models" (168). She also claims, again based on her data, that "there is no discernible cost or population threshold to explain the rate of diffusion of water works in New England towns" (155).

28. See Iowa City Daily Press, 9, 11 April, 1, 8, 29 May 1874; Minutes-Iowa City, 8 May 1874. 
local creek, did not see the necessity for a waterworks or a citywide sewer system. Instead it authorized construction of a new well, this one near the creek and therefore outside the "business portion, "in an effort to provide the water necessary to flush the creek. Unlike earlier expenditures for public water, city leaders dug this well not as an aid to fire fighters, but for the dual purpose of helping a local business and ending a complaintprovoking nuisance. ${ }^{29}$

The shift in perceptions of public water supplies gained momentum in 1877, the year the Marshalltown works opened. In the same year Iowa City indulged in a spree of well boring. Once again the motive was no longer merely fire protection. Instead, local businessmen petitioned the city council to build more wells at various locations as an "accommodation" to traders coming into town. Council members agreed that it was of "the utmost importance that farmers and others" be provided with water for livestock on market days. A combination of city money and subscription donations paid the cost of at least four wells during 1877. Not everyone supported these projects. When local businessmen solicited subscriptions for a well project at one of the busiest corners in the city, one newspaper denounced the location as "manifestly improper." The spot provided scarcely enough room for local merchants and street traffic, the writer complained, let alone another "pump and water trough." One or two wells were a "convenience," but if "every corner want[ed] one it [would] ... be a nuisance." "Digging wells on every corner is the work of villages far removed from streams," it claimed; "waterworks is the work of a city." Marshalltown, proclaimed another city newspaper, enjoyed one "mark of superiority" over Iowa City: its waterworks. The fire chief joined the chorus, too. As he presented city fire fighters to the mayor for the annual fire department review in 1877 . he remarked that it was high time the city consider building a works. ${ }^{30}$

29. Iowa City Daily Press, 11 April, 8 June, 3 July 1874. See also ibid., 9 April, 1, 8, 29 May, 18, 27 July, 5 August 1874; and Minutes-Iowa City, 1, 8 May, 17 July, 5, 7 August 1874 .

30. Minutes-Iowa City, 2 June 1876; Iowa City Republican, 8, 9 August 1877; Iowa City Daily Press, 11, 14, 25 August, 3 September, 30 October 1877. 
The agitation finally came to a head in 1878 and 1879 when citizens again complained about the amount of sewage generated by the hotel and some nearby breweries. One solution, noted a special council committee investigating the problem, would be to forbid further dumping in the creeks, an extreme measure that would force businesses to move from the city. Another solution would be to build a "complete system of sewers for the entire city," an endeavor that would be futile unless the city first built a waterworks. ${ }^{31}$ The desire for continued commercial prosperity had again collided head-on with citizen demands for a clean city. For the first time, city leaders began seriously considering a plan to build a waterworks. Council members working in special committees and in cooperation with other Iowa Citians began a lengthy informationgathering process: the city engineer collected data on various waterworks systems; special committees corresponded with other Iowa cities to gather information about water hydrant rents, and conferred with a local group of "capitalists" that had organized to build a works; other citizens investigated waterworks already in operation at nearby Cedar Rapids and Muscatine. ${ }^{32}$

In September 1879, however, 185 residents, apparently fearful of escalating tax burdens, petitioned the council to abandon the proposal. The city council subsequently voted against preparing an ordinance for building the works. One resident described the veto as a "crushing blow" to the city's prosperity: if the council continued such lunacy, Iowa City would simply lapse into "municipal decay." The setback was only temporary, though. Local newspapers continued to promote the idea, one pointing out that it was the "commonly accepted faith of the public that a town with [water was] worth living in." By the end of 1880 the council had written a waterworks ordinance, and townspeople ushered in 1881 with an intense debate, conducted in local newspapers, not over whether to build the works, but about who should own it. Some Iowa

31. Iowa City Daily Press, 1 May 1879; Minutes-Iowa City, 16 May, 6 June, 16 July 1879.

32. Iowa City Daily Press, 17, 18, 22 July, 2, 3, 6, 14 August, 6 September 1879; Minutes-Iowa City, 1 August 1879. 
Citians feared that the proposed ordinance gave the city too much power over a tax-supported works: only authorized people, such as fire fighters, would be allowed to use hydrants, even though all taxpayers would be footing the bill for installation. Another troubling facet of the ordinance was that once a customer tapped into the water system, his or her household plumbing would become virtual property of the water company, since only authorized plumbers would be allowed to install, repair, or inspect the necessary pipework. One citizen responded to the complaints by pointing out that a waterworks was a complicated business requiring management by "experts," adding that the proposed ordinance was scarcely unique, since in all respects it resembled "every known [water] charter in the country." 33

The debate and doubts slowed the council's decisionmaking process. Further readings of the ordinance were postponed as the council appointed still more special investigative committees. Two of the committees traveled to Marshalltown, Cedar Rapids, Muscatine, and Oskaloosa to study the works there, while another made a general study of the subject to determine the best method of water supply and its costs. By May 1881 council members had decided in favor of private ownership and set the necessary wheels in motion. The city initially agreed to rent seventy-five hydrants. In exchange, the works builder granted the city free water for use on streets, parks, and other public property, as well as in fountains, public watering troughs, and drinking fountains. The city retained control over water rates, which were to be set at levels comparable to those paid in other Iowa cities. Council also demanded that the contractor use "Holly quadruplex compound condensing pumping engines." 34

33. Iowa City Daily Press, 8 September, 12 December 1879,12 January, 7 February, 16 March 1880; Iowa City Republican, 30 December 1880, 5, 6, 7, 8 January 1881; Minutes-Iowa City, 5 September 1879, 17 December 1880.

34. For council actions, see Minutes-Iowa City, 4 February, 20, 24, 25, 26 May, 7, 27 June 1881; Iowa City Republican, 5 February, 21 May 1881. For An ordinance to provide a supply of water for the inhabitants of lowa City, Iowa, for domestic, fire use protection, and for other purposes, see Iowa City Republican, 7 June 1881. See also History of Johnson County, Iowa, 686-87. 
Unfortunately, the city's first contractor, a group of local investors, defaulted on the agreement. By the spring of 1882 not a foot of mains had been laid, forcing the council to retrace its steps, rewrite the ordinance, take new bids, and sign another contract. This time the council went outside the city to hire a Muscatine builder who had already constructed eighteen waterworks, ten of them in Iowa. The company broke ground in August. By the following February eighteen hydrants were working. The finished plant, with four main pumps and two backups, had the capacity to pump three million gallons of water per day. Iowa City had made a huge stride toward reaching "the station she ought to fill." ${ }^{\text {"35 }}$

Efforts to reach the same station in Boone stumbled over the problem of water supply. Unlike Iowa City and Marshalltown, Boone was not located directly on a river; finding a sufficient quantity of water proved difficult, costly, and timeconsuming. In the second half of the 1870 s officials enlarged the city's water storage capacity, mainly by building more cisterns and adding pumps to existing wells. By early 1880, however, the city council, in the face of continued journalistic pressure to build a waterworks, began studying alternatives to the city's fire cisterns. These included a plan to bore a "flowing well" and a proposal to dam the creek that ran through Boone in order to create a "magnificent little lake." The latter, commented one local newspaper, would be of "great utility" in providing a continuous water supply for "general purposes," including manufacturing. In addition, representatives of various waterworks companies spoke to the council, explaining the benefits of their respective systems. Council members needed little convincing; in August they appropriated fifteen thousand dollars to build a well-based waterworks. Several companies submitted bids and proposals, and in late 1880 the council selected a plan that included construction of a tank thirty feet in diameter,

35. Iowa City Daily Press, 3 June 1879; Iowa City Republican, 22 April, 4, 10 May, 15, 18, 19 July, 18 August, 7 September, 17, 22 October 1882, 6, 19, 24 January 1883; Minutes-Iowa City, 3, 9 May, 17 July, 4 September 1882, 9 February 1883. 
a wooden support structure, a brick engine house, and cast iron mains. ${ }^{36}$

The council moved with remarkable speed and unanimity in making decisions on ownership, technology, and finances. In the spring of 1881 , however, finding a suitable water supply emerged as a serious stumbling block. Council members wisely voted to delay construction until a test of each proposed site proved that an adequate supply of water could be found. That process dragged on for more than a year, with no satisfactory results. As disappointment followed disappointment and the search slowly devoured the appropriated funds, some residents began to question the council's approach. Finding water, hinted one paper, was like building a house: for that job one hired a "competent architect"; building a waterworks required an engineer. The council conferred with "business men and property holders," a meeting that left "no doubt that so far as public sentiment [was] concerned, the city [was] ready for water," but that "the best economy" dictated that the examinations "be made under the supervision of an expert." ${ }^{\prime 3}$

Council members took the advice to heart. Besides obtaining a mass of information from other cities and waterworks contractors, they also hired one engineer to survey the city, and another to draw up a set of plans for the works. A local paper applauded these moves, noting that asking for "professional help" was a "sign of wisdom."38 Ultimately the works engineer developed, with the council's approval, a plan using wells, a large tank, and hydraulic pumps. Construction began in the spring of 1884 , four years after the initial proposal. During the

36. Boone County Republican, 27 February, 13, 20 March 1878, 30 June, 25 February, 17 March, 9 June 1880; Minutes-Boone, 6 March, 29 May 1878, 7. May, 10, 26 June, 19, 30 August, 1, 24, September, 11 October, 1, 10 November 1880. See also An Ordinance to authorize the issuing of Bonds for Waterworks and to provide for payment thereof, Boone Ordinance Record No. 2, 164-65, City Clerk's Office, Boone.

37. Boone County Republican, 27 April, 4 May 1881; Boone Standard, 3 June, 22 July, 3, 19 August, 14, 21 October, 2 December 1882, 12, 24 February, 3 March 1883; Minutes-Boone, 26 April, 1 June 1881, 3 May, 6 December 1882.

38. Boone Standard, 7 April, 10 March, 5, 19 May, 14, 21, 28 July, 8, 22 September, 17 November 1883; Minutes-Boone, 29 June, 6, 11, 18, 24 July, 19, 20 September, 3 October, 14 November 1883. 
summer the city council passed several governing ordinances that copied those used in Marshalltown and Iowa City. The works themselves consisted of a twenty-two-foot-high steel tank on a one-hundred-foot brick tower. An "air-lift system" forced water from the wells into the tank; from there an eight-inch pipe carried the water to mains laid throughout the town. When a fire emergency demanded higher pressure, the pipe could be disconnected from the mains, and the water forced directly from the wells into the hydrants. After the official test of the works in August 1884, one newspaper noted with satisfaction that the pressure allowed fire fighters to throw a water stream higher than any building in town. On September 3,1884, city council members officially accepted the works from the contractor. ${ }^{39}$

BETWEEN 1876 and 1885 Boone, Iowa City, and Marshalltown dramatically altered the scope and nature of their public water supplies. They did so out of a desire to create up-to-date cities that would attract manufacturers and spur population growth. Residents' decisions to build waterworks occurred not in an atmosphere of crisis, as perhaps had been the case in the larger cities at mid-century. In Marshalltown the decision to construct a works did follow immediately on the heels of a large fire. Yet that fire came to be seen as a genuine crisis not when rickety buildings and overcrowded living conditions combined

39. Minutes-Boone, 6 February, 12 April, 3 September 1884; Boone Standard, 17 May, 14 June, 9 August 1884; An ordinance concerning the Waterworks of the City of Boone, lowa and establishing water rates, rules, regulations and penalties for the government of water takers, licensed plumbers and others, Boone Ordinance Record No. 2, 232-46; An ordinance for the protection of the Waterworks of the City of Boone, together with the pipes, hydrants, and other apparatus from injury and damage, printed in Boone Standard, 2 August 1884. Another description of the works is in Goldthwait, History of Boone County, 435-36. Unfortunately, Boone's struggle to find a satisfactory water supply was only beginning. In 1887 a severe drought forced a search for new wells, a process that proved to be almost as timeconsuming and costly as the first search. Not until 1912 did the city finally build what some residents had dreamed of earlier: a river-based pump waterworks like Marshalltown's. See Minutes-Boone, 10, 15 August 1887, 30 July 1888, 6 February 1889, 21 August 1890, 6 May 1891; Boone County Republican, 26 October 1887, 11 January, 20 August, 3 September, 10 October 1888, 12, 20 March 1889. For a description of the river pumping station, see Goldthwait, History of Boone County, 436. 
to make fire a constant threat, but when the possibility of fire threatened the community's image. If Marshalltown gained a reputation as a city with inadequate fire protection, the argument went, manufacturers would be less likely to settle there.

Similarly, Iowa Citians' complaints about sewage in the creeks provided a catalyst for actions that led to the construction of a waterworks, but the situation was neither lifethreatening nor disease-producing. Residents in all three cities complained routinely about the smell and sewage in local creeks, which were used as dumps for garbage and wastes. Every spring and summer local newspaper editors accused the marshal of neglecting to enforce ordinances against nuisances, two of which were stagnant water and noxious odors. There was little new about the complaint itself; what was new was the proposed solution-a sewer system, which, as residents realized, could not be built without a waterworks. If Iowa Citians faced a "crisis" of urbanization, then, it was one prompted by the need to find a way to allow the hotel and breweries to continue their operations in the city. In the 1870 s and 1880 s these Iowans used municipal services as tools for community growth and prosperity, not as solutions to threats posed by fire, social problems, industrialization, overcrowding, or other urban ills.

In this important respect the cases of Marshalltown, Boone, and Iowa City stand in contrast to those of much larger cities that built waterwcrks in the first half of the century. As some historians have pointed out, Americans at mid-century saw poverty, disease, and moral degeneration as being all of a piece. The desire to "clean up" the city, to rid it of filth and therefore of disease, crime, and other social evils motivated urbanites to erect large-scale waterworks in the nation's biggest cities in the 1840 s through the $1850 \mathrm{~s}$. It is no surprise, then, that historians have interpreted the evils of overcrowding, insufficient water supply, and consequent rises in disease and mortality rates as offshoots of urbanization that led Americans to develop municipal services; urbanization leads to chaos, which in turn leads to municipal services. The evidence from these three Iowa cities, however, does not fit this interpretation. Instead, municipal leaders there acted on the question of waterworks in order to create safe cities, where the presence 
of up-to-date municipal services would lure investors and manufacturers. ${ }^{40}$

DESPITE THE BENEFITS, real or imagined, of waterworks, their operation and management posed new municipal problems, as residents in all three cities learned during the 1880 s. City fire fighters had to learn how to work with hydrants and hoses, rather than buckets and hand pumps. In lowa City the waterworks manager devoted considerable energy to drilling the men in the use of pressurized water and the intricacies of hydrants and spanners. One engine company reorganized as a fire police since the department no longer needed it to operate the hand-pump engine, and the chief asked the council to purchase more hose and hose carts, so they could be distributed equally throughout the entire "water limits," that is, the part of the city served by hydrants. In Marshalltown and Boone, townspeople ensured adequate coordination between the works and the fire houses by installing various mechanical devices that rang fire alarms simultaneously at both places. ${ }^{41}$

The cities also discovered that after they acquired new water supplies, the existing sewer trenches, which had been built where and when they were needed, were no longer adequate. Now they found it more appropriate-and more efficient-to build systems of connected sewer mains that drained the whole city. Within five years of completing their waterworks, all three cities hired full-time engineers to develop plans and manage their construction. These citywide sewer

40. For a discussion of early nineteenth-century perceptions of the relationship between disease and moral degeneracy, see Charles E. Rosenberg, The Cholera Years: The United States in 1832, 1849 and 1866 (Chicago, 1962), 40-54, 74-75, 121-50; and George Rosen, A History of Public Health (New York, 1958), 236-38. For a different interpretation, see Alan I Marcus, "National History Through Local: Social Evils and the Origin of Municipal Services in Cincinnati," American Studies 23 (1981), 23-39. A discussion of the changing motives propelling the formation of municipal services is in Marcus, "National History Through Local," and Ogle, "Urban Growth in Iowa," chaps. 1 and 4.

41. Minutes-Iowa City, 3 November 1882, 5 January, 5 November 1883; Iowa City Republican, 13, 19 October 1882, 5 January, 14 February, 3, 7 March, 17, 18 May, 22 June, 25 July, 6 November 1883; MinutesMarshalltown, 23 October 1876, 3 June 1878, 17 March 1879. 
projects dwarfed the earlier ones of building waterworks, and their history raises a new set of issues. ${ }^{42}$

The problems of increased water usage and thus water disposal led to a turnaround in the cities' relationships with manufacturing concerns. During the 1870 s and 1880 s each city granted substantial tax exemptions to several manufacturers. Iowa City's city council, for example, remitted the taxes of the Grape Sugar Company for five years starting in 1880 . Boone extended the same inducement to local oil processing mills. Marshalltown remitted taxes and granted free water supplies or special water rates to several manufacturing concerns. ${ }^{43}$ These commercial enterprises used tremendous amounts of water, however, and the presence of waterworks increased industrial and domestic waste, creating a quantity of sewage that existing sewer systems, creeks, and drainage ditches could not handle. City leaders pleaded with residents and businesses to curb the "reckless waste of water" that "cripple[d] the efficiency" of the waterworks. ${ }^{44}$ Industrial water usage posed problems that the cities had not anticipated, however, and talk alone could not solve them. Marshalltown and Boone struggled over the subject of flat rates versus meters; the latter, the councils believed, would help curb wasteful practices by both domestic and industrial users. Boone officials opted for meters, contacted other cities using meters to determine the rates, and then wrote a new water use ordinance. ${ }^{45}$ Ironically, then, waterworks in

42. Minutes-Marshalltown, 26 March, 18 May, 27 October, 19 November 1883; Report of the Committee on Sewerage, in Annual Report of the Financial Condition of the City of Marshalltown (Marshalltown, 1885), 32-45; "Mayor's Address," in Financial Statement of the City of Marshalltown (Marshalltown, 1883), 4; Minutes-Boone, 1 July 1891, 27 May 1893, 19 July, 27 September 1893, 14 February 1894; Report of the Committee on Sewerage, published in Iowa City Republican, 17 July 1879; C. W. Irish, City Engineer, "Plan of Sewers for Iowa City," published in Iowa City Republican, 4 January 1883; "Recommendations for Sewers," Iowa City Republican, 31 August 1888; MinutesIowa City, 3 May 1889, 7, 18 August 1890, 6 February 1891.

43. Minutes-Boone, 7 September 1881, 6 June 1883, 25 March 1891; Minutes-Marshalltown, 12 April, 18 October 1880, 5 December 1881, 28 January, 18 August 1884, 22 September 1885, 12 October 1886; MinutesIowa City, 25 February 1880, 4 February 1881, 9 May 1884.

44. Minutes-Marshalltown, 18 March 1889.

45. Minutes-Boone, 19 September, 10 October 1885, 10 September 1888,7 June, 7 July, 8 November 1893; An ordinance repealing an ordinance con- 
these cities served not as a solution to problems of rapid urban growth and industrialization, but as the cause of a new set of urban woes. For better or worse, however, these three small municipalities had committed themselves to a major urban utility.

By failing to distinguish between time periods and sizes of cities, as well as the uses for which city residents intended a water supply, historians have overlooked the shifting ways Americans both defined and managed cities and their problems. When time and city size are taken into account, those changes come into sharper focus. Large metropolises such as New York, Chicago, and Boston each surpassed the ten thousand population mark before developing citywide multipurpose supplies of piped water in the 1850 s and 1860s. The residents of Iowa City, Boone, and Marshalltown, on the other hand, developed water service well before their populations had reached that mark and plunged the cities into chaos. Their decisions to build public waterworks stemmed from a redefinition of the form and uses of a "public" water supply. When they acted on that new definition and built waterworks between 1870 and 1890 , they did so not in response to growing pains, but out of a desire to spur community growth.

\footnotetext{
cerning the water rates, regulations and penalties for the government of water rates, licensed plumbers and others, and providing a substitute therefore [sic], in Ordinance Record No. 2, 450-59; Minutes-Marshalltown, 18 March, 13 May 1888, 12, 19 August, 14 October 1889, 10 February 1890; Annual Report of the Financial Conditions of the City of Marshalltown, 1886 (Marshalltown, 1886); An ordinance for the better inspection of water service and to prevent profuse and unlawful waste of water, in MinutesMarshalltown, 19 August 1889; and An ordinance concerning the water works department of the City of Marshalltown, lowa, and establishing water rates, rules, regulations, and penalties for the government of water takers, licensed plumbers and others and repealing chapter XXXV of the revised ordinances of 1887, Minutes-Marshalltown, 10 February 1895.
} 
Copyright of Annals of Iowa is the property of State of Iowa, by \& through the State Historical Society of Iowa and its content may not be copied or emailed to multiple sites or posted to a listserv without the copyright holder's express written permission. However, users may print, download, or email articles for individual use. 